KING STEPHEN 
Also in the Yale English Monarchs Series

EDWARD THE GONFESSOR by Frank Barlow

WILLIAM THE GONQUEROR by David Douglas*

WILLIAM RUFUS by Frank Barlow

HENRY I by Warren Hollister

KING STEPHEN by Edmund King

HENRY II by W. L. Warren

RICHARD I by John Gillingham

KING JOHN by W. L. Warren*

EDWARD I by Michael Prestwich

EDWARD II by Seymour Phillips

RICHARD II by Nigel Saul

HENRY V by Christopher Allmand

HENRY VI by Bertram Wolffe

EDWARD IV by Charles Ross

RICHARD III by Charles Ross

HENRY VII by S B Chrimes

HENRY VIII by JJ Scarisbrick

EDWARD VI by Jennifer Loach

JAMES II by John Miller

QUEEN ANNE by Edward Gregg

GEORGE I by Ragnhild Hatton

GEORGE II by Andrew Thompson

GEORGE III by Jeremy Black

GEORGE IV by E. A. Smith 


\section{KING STEPHEN}

Edmund King 
Copyright (C) 2010 Edmund King

All rights reserved. This book may not be reproduced in whole or in part, in any form (beyond that copying permitted by Sections I07 and 108 of the U.S. Copyright Law and except by reviewers for the public press) without written permission from the publishers.

For information about this and other Yale University Press publications, please contact: U.S. Office: sales.press@yale.edu www.yalebooks.com

Europe Office: sales@yaleup.co.uk www.yalebooks.co.uk

Set in Baskerville by IDSUK (DataConnection) Ltd

Printed in Great Britain by TJ International Ltd, Padstow, Cornwall

Library of Congress Cataloging-in-Publication Data

King, Edmund.

King Stephen / Edmund King. p. $\mathrm{cm}$.

ISBN 978-0-300-I $223-8$ (cl : alk. paper)

I. Stephen, King of England, I097?-II54. 2. Great

Britain-History-Stephen, I I35-II54· 3. Great Britain-Kings and rulers-Biography. I. Title.

DAig8.5.K 542010

942.02'4092 - dc22

[B]

$20100175^{11}$

A catalogue record for this book is available from the British Library.

Io 98765432 I 
For Michael and Frances 
